\title{
Industrial Clusters and CSR in Developing Countries: The Role of International Donor Funding
}

\author{
Anjum Fayyaz ${ }^{1} \cdot$ Peter Lund-Thomsen $^{2} \cdot$ Adam Lindgreen $^{3}$
}

Received: 13 October 2015/Accepted: 2 November 2015/Published online: 17 November 2015

(c) The Author(s) 2015. This article is published with open access at Springerlink.com

\begin{abstract}
This article contributes to literature on corporate social responsibility (CSR) exhibited by industrial clusters in developing countries. The authors conceptualize and empirically investigate the role of donor-funded CSR initiatives aimed at promoting collective action by clusterbased small- and medium-sized enterprises (SMEs). A case study of the Sialkot football-manufacturing cluster in Pakistan indicates that donor-funded support of CSR initiatives in industrial clusters in developing countries may be short-lived, due to the political economy of aid, the national context of CSR implementation, tensions within SME networks, and negative perceptions of CSR by the cluster-based SMEs themselves. The findings and implications of this analysis can inform both research and policy making in this area.
\end{abstract}

Keywords Corporate social responsibility · Donors · Football manufacturing $\cdot$ Industrial clusters $\cdot$ Sialkot $\cdot$ SME networking $\cdot$ Pakistan

Adam Lindgreen

lindgreena@cardiff.ac.uk

Anjum Fayyaz

anjum.fayyaz@lums.edu.pk

Peter Lund-Thomsen

plt.ikl@cbs.dk

1 Suleman Dawood School of Business, Lahore University of Management Sciences, Defence Housing Authority Lahore Cantonment, Lahore 54792, Pakistan

2 Center for Corporate Social Responsibility/Center for Business and Development Studies, Copenhagen Business School, Porcelænshaven 18A, 2000 Frederiksberg, Denmark

3 Department of Marketing and Strategy, Cardiff Business School, Cardiff University, Aberconway Building, Colum Drive, Cardiff CF10 3EU, UK
Industrial clusters, or agglomerations of small- and medium-sized firms (SMEs) ${ }^{1}$ in the same or related industries (Giuliani 2005), have great potential to enhance the competitiveness of export-oriented enterprises, create jobs in local economic regions, and enhance living standards in developing countries (Giuliani et al. 2005; Morrison et al. 2013; Pyke and Sengenberger 1992). Industrial clusters provide SMEs with both passive and active benefits. Passive benefits accrue as a result of the SMEs' co-location with other firms and institutions in a geographically confined space (Lund-Thomsen and Nadvi 2010). For example, local SMEs might benefit from the presence of input suppliers, specialized consultancy firms, a trained workforce, purchasing departments of national/international customers, or government support services (Nadvi 1999a). Such resources can stimulate learning processes and innovation among cluster-based SMEs, ultimately leading to increased sales and profit margins (Schmitz 2004). In terms of active benefits, SMEs in a cluster can intentionally collaborate, particularly with the help of business associations (Nadvi 1999a). For example, cluster-based firms actively cooperate to jointly purchase raw materials, engage in collective export-oriented marketing, and find common solutions to financing or logistics challenges (UNIDO 2013). Unanimous agreement in the industrial cluster literature indicates that such clusters have the potential to enhance industrial development processes in local economic regions in developing countries (Gereffi and Lee 2014; Giuliani et al. 2005; Nadvi 1999b; Schmitz 2004).

Whereas the traditional cluster literature prioritizes the stimulation of local economic development processes, a

\footnotetext{
${ }^{1}$ For this study, SMEs are defined as companies with 250 or fewer employees.
} 
growing body of literature now seeks to investigate how clusters might increase the integration of economic, social, and environmental concerns into their firms' core business practices-that is, enhance corporate social responsibility (CSR) (Gereffi and Lee 2014; Giuliani 2014; Lund-Thomsen and Nadvi 2010; Lund-Thomsen and Pillay 2012; Puppim de Oliveira and Jabbour 2015). Perhaps the most extensive consideration of this topic is the recent special issue of Journal of Business Ethics that takes stock of this literature stream. In their overview article, Lund-Thomsen et al. (2014) argue that literature on CSR in industrial clusters is fairly limited, concentrated mostly on environmental pollution controls, labor rights issues (and child labor in particular), and poverty reduction. More recently, some efforts seek to conceptualize the promotion of CSR in industrial clusters, such as by identifying how so-called low-road, window-dressing (i.e., clusters that preach but do not practice CSR), and rights-oriented clusters contribute to or undermine the promotion of human rights (Giuliani 2014). Gereffi and Lee (2014) also suggest that improvements in the quantity and quality of jobs in industrial clusters may be linked to what they call private, social, and public governance, all of which drive forces of social upgrading in local industrial districts in the developing world. Knorringa and Nadvi (2014) further argue, in the context of the so-called Rising Power economies, that the formal and informal institutional context of clusters helps explain the (lack of) attention paid to social and environmental aspects of cluster development processes.

Yet one aspect remains underexplored: the influence of international donor agencies in facilitating or undermining collective action among SMEs in response to the CSR concerns of their foreign buyers (Lund-Thomsen and Pillay 2012). Donor funding is important, because it adds financial resources, know-how, expertise, and political attention (Easterly 2007) that otherwise might be neglected by local policy makers (Browne 2006). Furthermore, donor funding that aims specifically to promote the development of the private sector has increased significantly in recent years (Estrup 2009). But international funding agencies have also been accused of promoting poorly designed projects that were not formulated locally, or that failed to match the priorities of local governments or other stakeholders. Thus, Western funding agencies are sometimes perceived as agents of a wider, neo-imperialist project aimed at keeping developing countries dependent on former colonial powers (Hancock 1994). Using international donor funds to promote the private sector in developing countries may also distort local competition and markets (Estrup 2009). ${ }^{2}$

\footnotetext{
${ }^{2}$ In industrial clusters in developing countries, relatively few empirical studies investigate the potential or limits of donor funding
}

In this article, we contribute uniquely to literature on donor-supported CSR interventions in clusters in developing countries in conceptual, empirical, and managerial terms. First, we develop a conceptual framework of some factors that may explain why donor-sponsored CSR projects succeed or fail to promote collective action in industrial clusters in developing countries. In developing this framework, we combine insights from literature on international development aid, CSR in developing countries, and the role of clusters in regional development processes. Second, this article makes an empirical contribution related to international donor agencies and CSR in industrial clusters in developing countries, in that we analyze a case study of a donor-sponsored intervention in the Sialkot football-manufacturing industry of Pakistan. Our analysis demonstrates how and why this project was discontinued after a short implementation period. Third, in managerial terms, our article provides insights into the circumstances in which international aid agencies can(not) use CSR to support collective action processes in industrial clusters in developing countries. In this regard, our study focuses on an intervention sponsored by an international development agency (IDA), whose purpose was to ascertain if CSR could provide a foundation for a process of collective coordination in SME clusters in developing countries. We study a critical case of such a donor-supported project and find that factors related to the international political economy of aid, the national implementation context, internal conflicts among the SMEs, and skepticism toward CSR by the SMEs led to the discontinuation of the project.

The rest of the article is structured as follows: In the next section, we outline our analytical framework. We

Footnote 2 continued

for promoting CSR (e.g., Gulati 2012; de Oliveira and Fortes 2014). Some studies investigate work undertaken by international development agencies to promote CSR in the tannery and football clusters of Kasur and Sialkot, Pakistan, and the football-manufacturing cluster of Jalandhar, India. These studies mostly consider questions of the longterm ownership and sustainability of donor interventions to promote cluster-based CSR initiatives (Lund-Thomsen 2009; Lund-Thomsen and Nadvi 2009, 2010). A recent study of the Jalandhar cluster indicates that a donor agency promoted the long-term adoption of CSR practices within the cluster, but the CSR activities mostly took the form of philanthropy, without changing the core business practices of the local cluster-based SMEs or the work conditions for local employees (Jamali et al. 2015). In practitioner literature, the New Delhi-based Foundation for Medium, Small, and Microenterprises produced a three-volume report, covering the roles and responsibilities of policy makers, implementing agencies, and change agents ("cluster development agents"), from international donor agencies or national (government) agencies. The guidelines, recommendations, and best practice case examples focus on how-to ideas and what works (FMC 2013a, b, c). 
discuss and combine insights from literatures on international development aid, CSR in developing countries, and the role of industrial clusters in regional development processes. The resulting conceptual framework clarifies the circumstances in which donor-sponsored CSR projects are (un)likely to promote collective action in industrial clusters in developing countries. Next, we describe the methodology, sampling strategy, multiple data generation methods, and data analysis procedures. This section also introduces the project we study, which we call the CSR SME network. After providing an overview of the Sialkot football-manufacturing cluster, in which various CSR interventions have been undertaken, we present our empirical analysis of the CSR SME network in Sialkot, combining insights from our conceptual framework with the empirical analysis to uncover factors that led to the discontinuation of the CSR SME network in Pakistan. Finally, we highlight our main findings and draw implications for analyses and practices of donor-financed CSR interventions in industrial clusters in developing countries.

\section{Analytical Framework}

In this section, we explore, in conceptual terms, whether international donor-financed CSR projects help or hinder the promotion of collective action in industrial clusters in developing countries. We start by reviewing the international literature on the pros and cons of donor funding as a form of support for local change processes in the developing world.

\section{Political Economy of Aid}

As Table 1 summarizes, researchers in development studies often describe donor funding either as a blessing or a curse for promoting economic, social, and environmental change processes in developing countries (Parks 2008; Riddell 2007). International donor funding can contribute much needed financial resources in times of fiscal austerity, enabling the implementation of state, private sector, and government projects and programs (Groves and Hinton 2013). In particular, such financial support may lead to greater prioritization of issues such as human rights, health and social welfare provisioning, and the rights of women than would otherwise have been the case without the influence of international funding agencies (Mavrotas 2010). Non-traditional donors from the Brazil, Russia, India, China, and South Africa (BRICS) have also sponsored infrastructure improvements in other developing countries and economies in transition. At least in theory, such investments may induce positive spillovers in the form of local enterprise development and job creation (Mawdsley 2012).

Donor funding can also take nonfinancial forms, such as technical expertise or know-how that helps government, private sector, or nonprofit entities boost their administrative capabilities, human resource management techniques, or finance/accounting knowledge (Browne 2006). In addition to technical transfers of know-how, Western donor funding tends to be accompanied by participatory, genderfriendly policies and approaches to the workings of government, private sector, and nongovernmental

Table 1 Arguments for and against international donor funding

\begin{tabular}{|c|c|}
\hline Arguments for international aid & Arguments against international aid \\
\hline $\begin{array}{l}\text { International donor funding involves financial resource transfers that } \\
\text { make state, private sector, and government projects and programs } \\
\text { possible in times of financial austerity (Groves and Hinton 2013) }\end{array}$ & $\begin{array}{l}\text { Development aid is often wasted due to bureaucratic inefficiency, } \\
\text { misguided donor policies, excessive executive salaries, and political } \\
\text { corruption (Hancock 1994) }\end{array}$ \\
\hline $\begin{array}{l}\text { Donor funding ensures that policy areas such as human rights, health } \\
\text { and social welfare provisioning, and the rights of women receive } \\
\text { higher priority in developing countries than they would otherwise } \\
\text { (Mavrotas 2010) }\end{array}$ & $\begin{array}{l}\text { Western organizations are ineffective in mitigating global poverty. The } \\
\text { West needs to face its history of ineptitude and colonialism (Easterly } \\
\text { 2007) }\end{array}$ \\
\hline $\begin{array}{l}\text { Non-traditional donors from the BRICS and some Western donors } \\
\text { finance infrastructure improvement projects that-at least in theory- } \\
\text { provide positive spillovers in the form of local business and job } \\
\text { creation in developing countries (Mawdsley 2012) }\end{array}$ & $\begin{array}{l}\text { Donor funding is traditionally time-bound (e.g., between one and three } \\
\text { years), so an intense transfer of know-how and financial resources } \\
\text { must take place within this time frame, raising questions about the } \\
\text { long-term sustainability of such interventions (Lund-Thomsen 2009) }\end{array}$ \\
\hline $\begin{array}{l}\text { Donor funding in the form of technical expertise and know-how might } \\
\text { help local actors boost their administrative capabilities, human } \\
\text { resource management techniques, and finance and accounting } \\
\text { knowledge (Browne 2006) }\end{array}$ & $\begin{array}{l}\text { Donor interventions are often undertaken without sufficient } \\
\text { coordination, resulting in duplication and overlap of activities } \\
\text { (Nunnenkamp et al. 2013) }\end{array}$ \\
\hline $\begin{array}{l}\text { Donor funding promotes participatory and gender-friendly policies and } \\
\text { approaches in the developing world (Groves and Hinton 2013) }\end{array}$ & $\begin{array}{l}\text { Aid consultancy industries must help international donors monitor and } \\
\text { evaluate activities to ensure they serve the needs of the original target } \\
\text { groups in the developing world (Groves and Hinton 2013) }\end{array}$ \\
\hline
\end{tabular}


organizations (NGOs) in the developing world. Moreover, development aid in the form of financial or nonfinancial transfers may support economic, social, and environmental elements of local change processes in developing countries (Groves and Hinton 2013).

However, donor funding may in some circumstances become a curse (Easterly 2007). Traditionally, donor projects are time-bound interventions that last between 1 and 3 years. An intense transfer of know-how and financial resources must take place within this time frame. This raises questions about the long-term viability of such interventions when external financial and know-how resource flows no longer drive them (Lund-Thomsen 2009). This points to the importance of local ownership of development aid projects or programs, in that many projects are driven by external actors, according to their own interests, without involving local actors in their design, execution, or monitoring. Some donor interventions might thus prioritize policy areas that are not in line with the needs of developing country actors (Richmond 2012). Another criticism of donor-financed interventions notes that they often fail to ensure sufficient coordination with other governmental or donor initiatives, which can lead to duplicated efforts and overlapping activities (Nunnenkamp et al. 2013).

Finally, donor funding might create perverse incentives for various local actors (Easterly 2007). Some recipients of development aid-whether individuals or institutionsactively seek to attract donor funding that they subsequently use to sustain luxurious lifestyles, with few or no benefits reaching the intended beneficiaries (Hancock 1994). Entire aid consultancy industries have emerged in some developing countries, in response to the needs of international donors to monitor and evaluate aid interventions to ensure they serve the interests of the intended beneficiaries in the developing world and demonstrate results to tax payers and voters in developed countries (Groves and Hinton 2013).

In the past 15 years, the debate on donor-funded interventions in the developing world has focused increasingly on whether support to private sector firms enhances or undermines the development of national industries and companies (Kragelund 2005; Schulpen and Gibbon 2002). On the one hand, some of the preceding arguments also apply to private sector interventions. Donor-funded assistance might help local firms upgrade their products and production processes, move to higher value-added functions in the value chain, or use competitive skills learned in one industry to gain competitive advantages in another (Staritz 2012). Moreover, aid to private sector firms, particularly SMEs or microenterprises, may help address the capacity constraints that poor and marginalized groups often face in terms of their effective participation in local, national, or international value chains or markets (Humphrey and Navas-Aleman 2010). From this point of view, donor support to the private sector in developing countries should involve partnerships with international buyers (Altenburg 2007; Humphrey and Navas-Aleman 2010), because local firms in developing countries may be more likely to react to market-based incentives in the form of changing buyer demands. If donor-supported interventions involve buyers actively, the likelihood of developing country firms taking ownership of private sector development aid interventions is thought to increase (Pattaconi and Weisert 2013).

On the other hand, donor staff or hired consultants may lack knowledge and skills to run private enterprises, donor interventions may be poorly coordinated with national government agencies or other donors, local enterprises may not be sufficiently involved in the process of project formulation, and these local actors may lack interest in the issues addressed by the donor intervention, in that they will halt these activities once donor funding expires (LundThomsen 2009). Donor support in favor of private sector firms also might distort local competition and developing country markets by helping some local enterprises in their development at the expense of other firms that do not receive such support (Estrup 2009).

\section{National CSR Context}

The international political economy of aid has an important role in co-determining whether private sector donor interventions succeed, yet the national context of CSR also has implications for how such interventions fare. Literature on CSR acknowledges that national institutional contexts matter for how CSR is understood in distinct geographical settings (Brammer et al. 2012; Gond et al. 2011; Jamali et al. 2015). For this discussion, institutions refer to "the rules of the game in society or, more formally...the humanly devised constraints that shape human interaction" (North 1990, p. 3). For example, in their examination of how CSR was institutionalized in North American and European contexts, Matten and Moon (2008, p. 409) note that explicit CSR (which is more widespread in North America) involves corporate policies that define responsibility for broader societal interests, whereas implicit CSR (more prevalent in continental Europe) refers to norms, values, and rules that are institutionalized "in (mandatory and customary) requirements for corporations to address stakeholder issues and that define proper obligations of corporate actors in collective rather than individual terms."

However, institutional perspectives on CSR largely ignore so-called fragile states (Azizi and Jamali 2015). Broadly defined, fragile states are countries that share a common characteristic: "the inability-for whatever 
reason-to fulfill basic state functions" (Gisselquist 2014, p. 9). Fragility and governance are two interrelated but conceptually distinct notions. Fragility is a characteristic of the state; governance pertains to the institutions and norms characterizing how power gets exercised within a given sate. Therefore, state fragility may be a function of both weaknesses in state institutions and the functioning and priorities of national governments. Yet even democratic governments are in some instances unable to guarantee public security, uphold the rule of law, or provide public goods if their state institutions are weak or in need of substantial reform (Gisselquist 2014). Regarding aid provisioning in such contexts, the relative effectiveness of donor funding for stimulating local growth and reducing poverty appears significantly lower in fragile states than in other, more stable contexts. Therefore, both academics and policy makers question the capacity of fragile states to absorb aid efficiently (Feeny and McGillivray 2009).

Literature on donor support to fragile states highlights the need to take domestic factors and local contexts into account when designing aid interventions, while also advocating for local ownership of interventions. International-level actors can provide aid and reform incentives, but leadership at the national level is key for restoring confidence in domestic institutions (Gisselquist 2014). In our analytical framework, we expect that donor support to CSR in industrial clusters in developing countries is more challenging in fragile states, such as Pakistan. In other words, while donor funding has the potential to provide knowledge, expertise, and funds in support of local joint action in clusters in developing countries, its outcomes depend substantially on the relative state of public security, whether the rule of law can be enforced, and the extent to which the state can provide public goods in cluster settings.

\section{Collective Action in SME Clusters}

In this section, we explore how donor-financed CSR interventions relate to the promotion of collective action among SMEs in industrial clusters in developing countries. Prior literature predicts that SMEs in developing countries benefit from being co-located in geographically demarcated clusters, in both active and passive ways (Schmitz and Nadvi 1999). When firms in the same or related industries co-locate geographically (Giuliani 2005), SMEs may benefit in passive ways, because clusters grant them access to a skilled labor force, logistics and transportation providers based in the cluster, specialized input suppliers, and buying or sourcing offices that can help mediate customer requirements (Nadvi 1999b). Moreover, training institutes and locally available consultants likely facilitate upgrading of products, production processes, and human resources. Formal and informal SME networks ease the circulation of innovative ideas, production knowledge, and personnel, compared with the flows available to SMEs in the same industry that are geographically separated (Schmitz and Nadvi 1999). In addition, SME clusters may benefit in active ways from their co-location, because they can cooperate to address challenges such a lack of adequate infrastructure; the need for improved human resources, technology, or machinery; and ready sourcing of raw materials or marketing capabilities (Nadvi 1999a). Such joint initiatives may be undertaken through industry associations or in cooperation with public sector or international donor agencies.

With our analytical framework, we seek to identify circumstances in which donor-financed CSR projects provide a basis to support collective coordination in SME clusters in developing countries. Although clusters in developing countries have the potential to facilitate local economic development processes, they have also come under fire for engaging in socially or environmentally destructive activities (Blackman 2006). Evidence indicates that SMEs in leather tanning, foundry, and textile clusters in particular engage in highly polluting activities that threaten the health of local inhabitants and the environment, especially those located in Asia, Africa, and Latin America (Lund-Thomsen et al. 2014). Cluster-based SMEs have also been accused of using child and forced labor, paying below poverty-level wages, and generally squeezing workers' conditions in a downward spiral, competing in a "dirty" fashion with other local and international producers (Khan 2010).

Donor-financed CSR interventions then might play an important role in promoting collective action among SMEs to address the social and environmental externalities that arise from economic development processes in local clusters in the developing world, particularly by promoting CSR initiatives (Lund-Thomsen and Pillay 2012; Puppim de Oliveira and Jabbour 2015). In a related development, donor agencies have begun promoting value-chain interventions as a new form of private sector development aid (Humphrey and Navas-Aleman 2010; Staritz 2012), including the promotion of CSR in global value chains more broadly (Estrup 2009). The global value-chain literature highlights how local SMEs, selling in international markets, increasingly encounter more stringent social and environmental performance requirements by their international buyers (Egels-Zandén 2015; Skadesgaard Thorsen and Jeppesen 2010). In particular, international supermarkets, brands, and retailers appear to dominate and orchestrate vast supplier networks in developing countries. The concept of global value-chain governance in turn describes how these retailers dictate what kinds of products are to be produced, at what price, and in which social and environmental conditions in developing country export industries (Gibbon and Ponte 2005). Many social and environmental requirements are written down, in codes of conduct or 
ethical guidelines that suppliers of international buyers must follow. For example, suppliers commit to provide workers with minimum wages, overtime payments, and social insurance (Barrientos and Smith 2007).

We speculate that donor funding can help co-finance SME investments in social and environmental upgrading of factories (Lund-Thomsen and Pillay 2012). Moreover, donor funding could help facilitate compliance with CSR requirements of international buyers, because local cluster-based associations or formalized SME networks might share CSRrelated know-how and training (Nadvi 2004). Such shared know-how usually starts with local or international consultants. In addition, donor funding may be instrumental in gathering various stakeholders to participate in joint action initiatives that can ensure social and environmental improvements by SMEs in particular clusters (Khan 2007a, b).

\section{SME Perceptions of CSR}

However, international donor-financed CSR interventions, aimed at promoting collective action in industrial clusters in developing countries, may be unsuccessful if they do not build on a sufficiently strong business case for CSR (Gulati 2012). That is, there must be clear financial incentives for cluster-based SMEs to invest in social and environmental upgrading, whether in the form of cost reductions (e.g., reduce wasted raw materials), efficiency enhancements (e.g., increased labor productivity), higher prices paid by existing or new CSR-conscious buyers, or compliance with governmental regulations that either force the SMEs to upgrade or close down (Lund-Thomsen et al. 2014).

The donor financing of CSR initiatives might also be unsuccessful if cluster-based SMEs perceive the social and environmental priorities of the donor agencies as a form of economic or cultural imperialism (Khan and Lund-Thomsen 2011). Ruwanpura and Wrigley (2011) and De Neve (2014) explore the perceptions, by SME managers in the developing world, of CSR as a form of cultural and economic imperialism imposed on them by foreign customers. For example, the requirement against the use of child labor might be seen as a cultural imposition in contexts where children's work is regarded as a form of job training that will secure these children and their families a future source of livelihood in the absence of adequate, locally available, and affordable schooling options (Lund-Thomsen 2008). Similarly, SME managers may regard CSR as economic imperialism imposed by buyers that demand constant declines in unit prices but refuse to co-finance investments in social and environmental upgrading of factories, even while insisting that developing country suppliers be socially and environmentally responsible (Khan and Lund-Thomsen 2011).

Finally, donor-financed CSR interventions may be unsuccessful in promoting collective action among cluster-

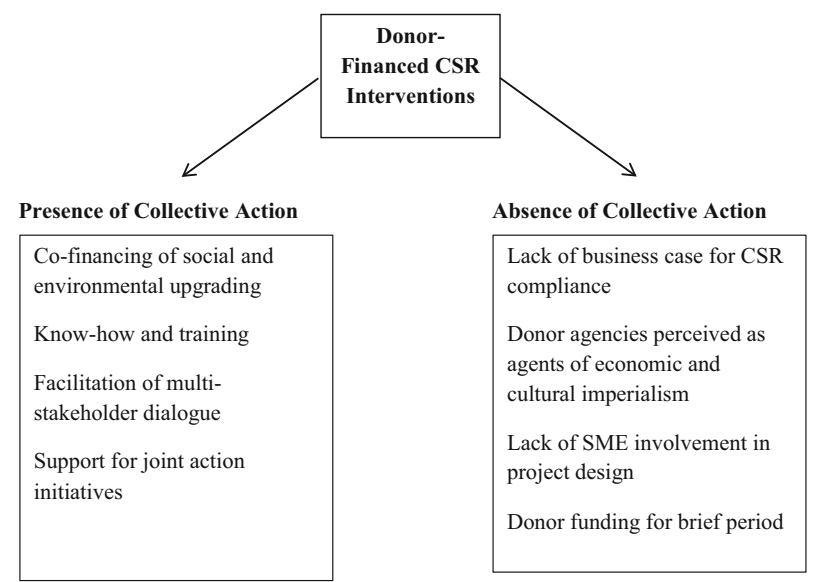

Fig. 1 Donor-financed CSR interventions and collective action in industrial clusters

based SMEs if the local enterprises have not been involved in the project formulation or execution or if the donor funding halts after a relatively short period, without allowing cluster-based SMEs to achieve sufficient levels of social and environmental upgrading prior to the termination of the project funding. Figure 1 summarizes this described analytical framework.

In short, in our analytical framework, donor-financed CSR interventions potentially catalyze collective action in industrial clusters in developing countries by co-financing social and environmental upgrading processes in clusterbased SMEs, transferring CSR know-how and training, facilitating multi-stakeholder dialogues, and involving local business associations in joint action initiatives. These donor-financed CSR interventions can help cluster-based SMEs address the CSR concerns of their international buyers on a collective basis in ways that would not have been possible for single SMEs. However, our analytical framework also recognizes that donor-funded CSR initiatives aimed at promoting collective action in industrial clusters in developing countries may not succeed if the cluster-based SMEs do not perceive a business case for engaging in CSR, view the donors as trying to promote their own imperialistic priorities, are not sufficiently involved in the project design, or do not receive donor funding for a sufficiently long period to establish the required levels of resources, trust, and collaboration.

\section{Methodology}

\section{Case Study Selection}

We use a qualitative methodology, so that we can investigate the complex phenomenon of donor-financed CSR interventions that might promote collective action among 
cluster-based SMEs in a specific socio-economic and socio-cultural context, taking multiple factors into account that might explain the process of (non)engagement in collective action in a particular cluster (Eisenhardt 1989; Reast et al. 2010, 2013; Yin 2013). We chose the Sialkot football-manufacturing cluster in Pakistan as the focus. This critical case study enables us to make inferences, of the type "If this is (not) valid for this case, then it applies to all (no) cases" (Flyvbjerg 2006, p. 230). That is, to test the prediction that donors can use CSR to promote collective action among SME networks in industrial clusters in developing countries, the Sialkot case study can likely yield useful insights. Cluster-based SMEs in Sialkot faced the immediate threat of losing international orders in 2007, following Nike's partial withdrawal from the cluster in response to unauthorized outsourcing of football stitching to home-based locations and evidence of labor rights violations at its main supplier Saga Sports (Seigmann 2008). If cluster-based SMEs in Sialkot did not use CSR issues as a basis for collective action in these circumstances, it seems unlikely that CSR would become the basis for sustained collective action in other clusters facing similar threats of buyer exit. Furthermore, political unrest, security threats, and the national law-and-order situation in Pakistan have made development interventions after 2001 extremely challenging to implement. If the focal IDA development project could succeed in these conditions, similar projects might be likely to succeed elsewhere in the developing world, especially in less challenging environments. Finally, we regard the Sialkot case as critical because previous studies document the strongly held "anti-CSR" feelings among local entrepreneurs and nonprofit workers, such that using CSR as an entry point for engaging SMEs in collective action might be particularly challenging in this context (Khan 2004; Khan and Lund-Thomsen 2011). If IDA can use CSR to promote collective action in Sialkot, entities elsewhere can likely do the same in other clusters in which SME managers are less skeptical of CSR. Overall, if the IDA CSR project can succeed in promoting collective action among cluster-based SMEs in Sialkot (a context dominated by buyer CSR concerns, political and security risks, and strongly held "anti-CSR" views), all else being equal, such interventions should be able to succeed in other, more politically stable clusters in developing countries.

\section{Case Description}

We investigate an aid project supported by IDA in Sialkot between 2008 and 2009, whose purpose was to ascertain if issues pertaining to CSR could provide a foundation for a process of collective action in SME clusters in developing countries. In general, IDA sought to enable SMEs in
Pakistan to achieve greater self-reliance by building institutions and strengthening local capacities. The Pakistani government was willing to finance IDA interventions in five pilot clusters as part of its broader trade policy. In 2003, the government of Pakistan approved and transferred US $\$ 211,000$ to a trust fund, under an agreement to intervene in these five pilot clusters. Yet the assistance to SME clusters in Pakistan was severely constrained, because IDA, in its own assessment, had very limited financial resources at its disposal to execute its cluster development program in Pakistan.

Within this broader framework, IDA decided to launch a Soccer Village project in Sialkot in 2008, which led to the establishment of a SME network of four football producers and exporters, under the leadership of the President of the Sialkot Chamber of Commerce and Industry. We refer to this network as the CSR SME network. Members were to cooperate in producing and marketing responsibly produced footballs. The IDA-backed Soccer Village project would co-fund activities undertaken by these Sialkot-based SMEs. Neither donor nor government funds were significantly invested, so the Soccer Village project relied heavily on in-kind subsidization from a parallel IDA project in India. After 18 months in operation, it ceased to function.

We investigate the development and discontinuation of this IDA-supported CSR SME network, using fieldwork that took place 2-3 years after the network dissolved in 2009. Our in-depth case study provides a rich, long-term perspective on the viability of donor-financed CSR interventions aimed at promoting collective action among cluster-based SME entrepreneurs in a highly challenging and complex context. It also features rarely investigated aspects of CSR, such as the discontinuation of the CSR project. Considering the conventional and widespread focus on best practice CSR case studies, we offer this case with the scientific awareness that sometimes we can learn just as much or more from cases in which things do not work out as hoped for.

Donor-financed CSR interventions in the Sialkot cluster have been studied extensively, in the form of projects supported by the International Labor Organization (ILO) and United Nations Children's Fund (e.g., Khan 2004; 2007a, b; Lund-Thomsen and Nadvi 2010). We focus on an intervention by IDA between 2008 and 2009 that has not been the subject of any academic studies (we offer a brief history of CSR interventions in Sialkot subsequently).

\section{Data Collection}

We develop a rich case history for the IDA CSR project in Sialkot and its attempt to promote collective action in the CSR SME network. In 25 semi-structured, qualitative interviews, conducted between March 2011 and October 
2012, with a broad range of stakeholders, we gained access to various interpretations of the CSR project, including both positive and skeptical views. We spoke to members of the network of Sialkot football entrepreneurs involved in the project; members of other SME networks in Sialkot; the Sialkot Chamber of Commerce; local NGOs such as the Independent Association for Monitoring Child Labor (IMAC) and the Child and Social Development Organization (CSDO); government representatives from the Trade Development Authority of Pakistan and the Small- and Medium-sized Enterprise Authority of Pakistan; international NGOs such as the International Labor Rights Fund (ILRF), and industry associations such as the World Federation of Sporting Goods based in Switzerland; international buyers such as Adidas (U.S.) and Select Sports (Danish) that sourced footballs from Sialkot; and present and former staff members from the European headquarters of IDA, the organization's Lahore office, and its field office in Sialkot.

The interviews were recorded digitally and lasted between 60 and $120 \mathrm{~min}$ each. If interviewees did not feel comfortable being recorded, we asked for permission to take detailed interview notes and then sent these notes to the interviewees for corrections and feedback. All interviews were fully transcribed. After we had conducted several interviews, we developed theoretical notes, as part of the process of building a grounded theory of why the IDA-sponsored project was discontinued (Strauss and Corbin 1998). This iterative process sharpened our research questions and theoretical focus for subsequent interviews.

During the interviews, we talked to informants about their perceptions of how and why the IDA-sponsored project was discontinued. The interviews mixed grand tour questions and interviewer prompts, to allow rich insights to emerge (McCracken 1986). They also focused on issues such as competitiveness and the CSR challenges faced by SMEs in the football-manufacturing industry of Pakistan, the history of SME networking in Sialkot, and sourcing links for SME network members with national and international buyers. We constantly engaged in dialectical thinking, making repeated comparisons among relevant literature, incoming data, and our emerging theory. Prior to each interview, we examined publicly available secondary material to gain further insights into the complex case. The use of multiple data sources was crucial for ensuring data triangulation and refining our final interpretation of the reasons for the discontinuation of the IDA-sponsored project (Strauss and Corbin 1998; Yin 2013). Table 2 contains an overview of each organization/interviewee, their stakeholder groups, their mission (general), their CSR role in Sialkot, and the reasons to include them in the study.

\section{Data Analysis}

As part of the data analysis process, we developed analytical categories with the help of open and axial coding procedures (Strauss and Corbin 1998), through repeated readings of literature on international donor funding, institutional approaches to CSR, industrial clusters in developing countries, and CSR in these contexts, in combination with our interview materials. During the open coding stage, we read and coded all parts of the interview transcripts with a view to identifying similarities and differences in interviewees' perceptions of how and why the IDA project had been discontinued. We each engaged in our own independent analysis, exchanging notes on our coding. Furthermore, we engaged in repeated discussion, agreement, and disagreement about different parts of the analysis. We then moved to the process of axial coding, identifying higher-level categories to understand the main reasons for how and why the IDA project had been discontinued. Accordingly, we generated four categories: the political economy of aid in Sialkot, the national context of Pakistan, joint action among SMEs in Sialkot, and SME perceptions of CSR in Sialkot. Finally, we used selective coding with a review, to refine our emerging theory of how and why the IDA-sponsored CSR project in Sialkot stopped. As part of our final quality control effort, we shared a draft manuscript with researchers that had intimate knowledge of the Sialkot cluster and donor-funded CSR interventions in general and then incorporated their comments. We also sent a draft to study informants, which helped us ensure the factual accuracy of the manuscript and refine our interpretation of events as they occurred in the IDA CSR project in Sialkot (Pole and Lampard 2002).

\section{The Cluster Context in Sialkot}

The Sialkot football-manufacturing industry in Pakistan is one of the most widely studied industrial clusters in the developing world. Several authors have written about issues of child labor (Khan 2004, 2007a, b; 2010), labor rights (Seigmann 2008), labor agency (Lund-Thomsen 2013), global value-chain linkages, local CSR approaches (Lund-Thomsen and Nadvi 2009, 2010), and technological upgrading in Sialkot as well as labor standards (Nadvi 2011; Nadvi et al. 2011), and comparative work conditions relative to other football-manufacturing countries in Asia (Chan and Xue 2013; Lund-Thomsen et al. 2012). As should be obvious from this list, most prior literature focuses on labor issues. An overview of the key findings, limitations, and insights into the role of donor-financed CSR interventions in these studies appears in the Appendix Table 4 . The popularity of such studies may reflect the 
Table 2 Types of interviewees and reasons for inclusion in the study

\begin{tabular}{|c|c|c|c|c|c|}
\hline Organization type & $\begin{array}{l}\text { Number of } \\
\text { interviewees }\end{array}$ & $\begin{array}{l}\text { Stakeholder } \\
\text { group }\end{array}$ & Mission (general) & Role in CSR in Sialkot & Reasons for inclusion \\
\hline Manufacturers & Seven & Exporter & $\begin{array}{l}\text { Increase profits from the } \\
\text { production and export of } \\
\text { footballs from Sialkot }\end{array}$ & $\begin{array}{l}\text { Often requested by } \\
\text { international buyers to } \\
\text { ensure compliance with } \\
\text { CSR requirements. } \\
\text { Sometimes engaged in } \\
\text { philanthropy as well }\end{array}$ & $\begin{array}{l}\text { Manufacturers were key } \\
\text { actors in IDA's attempt to } \\
\text { use CSR to promote } \\
\text { collective action among } \\
\text { cluster-based SMEs in } \\
\text { Sialkot }\end{array}$ \\
\hline Buyers & Three & Importer & $\begin{array}{l}\text { Source footballs of the best } \\
\text { possible quality at the } \\
\text { cheapest possible price }\end{array}$ & $\begin{array}{l}\text { Need to protect their brand } \\
\text { reputation with customers, } \\
\text { trade unions, regulatory } \\
\text { bodies, and media. CSR } \\
\text { thus was a part of the risk- } \\
\text { management strategies } \\
\text { and, for some brands, } \\
\text { overall business } \\
\text { development activities }\end{array}$ & $\begin{array}{l}\text { Responding to the CSR } \\
\text { concerns and priorities of } \\
\text { international buyers was } \\
\text { an important part of the } \\
\text { rationale for launching the } \\
\text { CSR SME network }\end{array}$ \\
\hline $\begin{array}{l}\text { National and } \\
\text { international } \\
\text { business } \\
\text { associations }\end{array}$ & Three & Industry body & $\begin{array}{l}\text { Articulate the common } \\
\text { interests of members and } \\
\text { help them address issues } \\
\text { that firms might benefit } \\
\text { from addressing on a } \\
\text { collective rather than an } \\
\text { individual basis }\end{array}$ & $\begin{array}{l}\text { Drive and implement } \\
\text { collective action CSR } \\
\text { initiatives in Sialkot }\end{array}$ & $\begin{array}{l}\text { The President of the Sialkot } \\
\text { Chamber of Commerce } \\
\text { played an important role } \\
\text { in the IDA CSR project }\end{array}$ \\
\hline $\begin{array}{l}\text { Nongovernmental } \\
\text { organizations }\end{array}$ & Three & Civil society & $\begin{array}{l}\text { Advocate against labor } \\
\text { rights abuses and help } \\
\text { eradicate child labor }\end{array}$ & $\begin{array}{l}\text { Expose labor rights abuses, } \\
\text { engage in child labor } \\
\text { monitoring or implement } \\
\text { social projects transferring } \\
\text { children from work to } \\
\text { schooling }\end{array}$ & $\begin{array}{l}\text { NGOs played an important } \\
\text { role of exposing child } \\
\text { labor in the Sialkot } \\
\text { football-manufacturing } \\
\text { cluster and in the } \\
\text { implementation of the } \\
\text { Atlanta Agreement }\end{array}$ \\
\hline $\begin{array}{l}\text { Government } \\
\text { agencies }\end{array}$ & Two & $\begin{array}{l}\text { State } \\
\text { representative }\end{array}$ & $\begin{array}{l}\text { Significant role in designing } \\
\text { industrial policies that } \\
\text { affect the entrepreneurs in } \\
\text { Sialkot. They also provide } \\
\text { support services to SMEs } \\
\text { and are supposed to } \\
\text { regulate their activities }\end{array}$ & $\begin{array}{l}\text { Governmental agencies } \\
\text { have helped support some } \\
\text { collective action } \\
\text { initiatives in Sialkot, but } \\
\text { they have also been } \\
\text { accused of not ensuring } \\
\text { that national labor and } \\
\text { environmental laws are } \\
\text { implemented by SMEs in } \\
\text { Sialkot }\end{array}$ & $\begin{array}{l}\text { Governmental support } \\
\text { agencies supported other } \\
\text { SME networks in Sialkot } \\
\text { while they were not } \\
\text { directly involved in the } \\
\text { IDA project }\end{array}$ \\
\hline Academics & Four & $\begin{array}{c}\text { Independent } \\
\text { observers }\end{array}$ & $\begin{array}{l}\text { To conduct independent } \\
\text { academic research, teach } \\
\text { and supervise students, } \\
\text { and communicate expert } \\
\text { knowledge to the broader } \\
\text { public }\end{array}$ & $\begin{array}{l}\text { Independent academics } \\
\text { have conducted several } \\
\text { studies of the background, } \\
\text { history, and effects of } \\
\text { CSR interventions in } \\
\text { Sialkot }\end{array}$ & $\begin{array}{l}\text { To obtain an independent } \\
\text { view of the unfolding of } \\
\text { the IDA project and the } \\
\text { reasons for its } \\
\text { discontinuation }\end{array}$ \\
\hline IDA & Three & $\begin{array}{l}\text { Donor funding } \\
\text { agency }\end{array}$ & $\begin{array}{l}\text { To support economically, } \\
\text { environmentally, and } \\
\text { socially sustainable } \\
\text { industrial development } \\
\text { processes }\end{array}$ & $\begin{array}{l}\text { Key driver of the } \\
\text { establishment of the CSR } \\
\text { SME network in Sialkot. } \\
\text { IDA also made the final } \\
\text { decision to discontinue the } \\
\text { CSR SME network }\end{array}$ & $\begin{array}{l}\text { To obtain its view on the } \\
\text { development and } \\
\text { discontinuation of the } \\
\text { CSR SME network in } \\
\text { Sialkot }\end{array}$ \\
\hline
\end{tabular}

integration of this cluster into global value chains that link local Sialkot football producers in Pakistan to world-famous sports brands such as Nike, Puma, Adidas, Mikasa, and Mitre.
Located in the province of Punjab, close to Pakistan's border with India, the Sialkot football-manufacturing cluster is scattered across the city and also spreads, through subcontracting networks, to stitching units in villages 
Table 3 Timeline of CSR challenges and solutions in the Sialkot cluster

\begin{tabular}{lll}
\hline Time & Challenge & Solutions \\
\hline Mid-1990s & $\begin{array}{c}\text { Media exposes child labor in the football stitching value chains } \\
\text { of global brand manufacturers in Sialkot } \\
\text { Discovery of unauthorized outsourcing of football stitching and } \\
\text { labor rights violations at Saga Sports, Nike's key football } \\
\text { supplier in Sialkot }\end{array}$ & $\begin{array}{l}\text { Atlanta agreement } \\
\text { Nike ends relationship with Saga Sports and redirects sourcing } \\
\text { to China and Thailand. Nike then re-enters Sialkot, } \\
\text { cooperating with a new vendor, Silverstar that promised to } \\
\text { meet Nike's code of conduct }\end{array}$ \\
$\begin{array}{l}\text { The Nike crisis threatens the viability of the cluster, and fears } \\
\text { loom that other buyers will follow Nike in leaving Sialkot }\end{array}$ & $\begin{array}{c}\text { International funding agencies such as IDA seek to introduce } \\
\text { new CSR projects and concepts, such as the Soccer Village } \\
\text { project }\end{array}$ \\
\hline
\end{tabular}

around the city. The football-manufacturing cluster supply chain features four tiers: large enterprises (20), medium enterprises $(50+)$, small or microenterprises $(400+)$, and subcontractors, whether makers or vendors $(1000+)$, which employed about 20,000 registered workers in 2014.

This local manufacturing value chain produces a range of footballs: professional match balls, practice/camp balls, promotional balls, indoor balls, and futsal soccer balls. The Sialkot football-manufacturing cluster has traditionally been known for its hand-stitched footballs, though international demand for hand-stitched balls has dropped significantly in the past decade, and the industry is in a state of transition toward more mechanized forms of production, including machine-stitched footballs and thermo-molded technology. The industry also faces significant competitive challenges from producers in China that have been quicker to adopt the new, more technologically advanced machinestitched and thermo-molded production methods. Apart from industries in Pakistan and China, India and Thailand are among the main production locations for football manufacturing worldwide (Nadvi et al. 2011).

The focus on CSR compliance in the Sialkot cluster can be traced back to the early to mid-1990s, when international news reports highlighted the use of child labor in the stitching subcontracting networks that linked exporting firms inside Sialkot to vast networks of contractors and home-based stitchers in the surrounding villages (Khan 2004). Children often helped their parents in stitching footballs, sometimes at the expense of their formal schooling. In 1997, a large multi-stakeholder initiative, involving United Nations agencies, the ILO, Save the Children, and the Sialkot Chamber of Commerce, sought to eradicate child labor from the industry (Lund-Thomsen and Nadvi 2010). Backed by international sports brands, the initiative aimed to transfer child stitchers from home-based work to formal schools in the Sialkot district, establish a cluster-wide mechanism for monitoring child labor, and retrain or compensate families to make up for the loss of income associated with their children leaving the occupation and entering formal schooling (Khan 2007a, b). This multi-stakeholder initiative, also known as the Atlanta agreement, largely eliminated the use of child labor from football stitching in Sialkot, though it also had the unintended side effect of excluding female workers from the stitching supply chain. Male family members would often not permit women to venture beyond the confines of their own homes to engage in any kind of work outside the home (Khan 2007a, b; Lund-Thomsen et al. 2012).

Despite the initial success of the Atlanta agreement, in terms of eliminating child labor from the cluster, wider concerns about labor rights persisted. The Sialkot cluster seemingly addressed the issue of child labor, but international sports brands moved on, demanding compliance with a wider range of labor rights, such as the use of formal contracts, minimum wages, and social insurance for stitchers (Seigmann 2008). The vast majority of these stitchers were undertaking their work in semi-formal, village-based stitching centers or at home, where these labor rights were not guaranteed. Thus, there was an increasing mismatch between the CSR demands of the cluster's international buyers and what the local SMEs could offer in terms of CSR compliance (ILRF 2010). In addition, international buyers were concerned about the lack of technological upgrading and innovation in the cluster, as local manufacturers had not switched sufficiently quickly from hand- to machine-stitching or thermo-molded production (Lund-Thomsen 2013).

As we describe in Table 3, within this wider context, Nike decided to stop sourcing footballs from what was then the world's largest manufacturer, Saga Sports, in late 2006, allegedly due to its unauthorized outsourcing of football stitching from village-based stitching centers to homebased locations in the Sialkot district. Although no child labor was found in Nike's supply chain, the risk of children being involved in football stitching constituted a major reputational threat to Nike (Lund-Thomsen and Coe 2015). Nike attempted to engage in remediation with Saga Sports over an extended, six-month period, to find a solution, but 
it did not appear as if Saga Sports realized the gravity of the concern. Therefore, Nike withdrew officially from not just Saga Sports but the Sialkot cluster as such (Seigmann 2008). In doing so, it attempted to redirect its sourcing of hand-stitched footballs to China and Thailand but discovered, in early 2007 , that some of the continued demand for high-quality, hand-stitched footballs could only be met by Pakistani manufacturers. In the spring of 2007, Nike reentered Sialkot, sourcing a smaller volume of hand-stitched balls from a new vendor that agreed to Nike's code of conduct and guaranteed that all hand stitching of footballs would take place inside its factory premises (Nadvi 2011).

The exit of Nike from Sialkot sparked the interest of international donor agencies, which sought to help the cluster address CSR issues, so that it could ensure the continued, long-term viability of local enterprises, employment, and incomes in Sialkot at a time when international buyers appeared to be searching for more "CSR-safe" production locations (Lund-Thomsen and Nadvi 2009; Skadesgaard and Jeppesen 2011). ${ }^{3}$

\section{Empirical Findings}

We detail our empirical findings by analyzing the factors that contributed to the discontinuation of the CSR SME network in Sialkot. These factors reflect the four categories derived from the coding of the interview data: (1) the political economy of aid in Sialkot, (2) the national context of Pakistan, (3) joint action among SMEs in Sialkot, and (4) SME perceptions of CSR in Sialkot.

\footnotetext{
3 The Sialkot Chamber of Commerce already had established a CSR cell and a Child and Social Development Organization (CSDO), with the help and support of WFSGI and FIFA, to promote social development programs within the cluster and coordinate social protection initiatives from the industry. The ILO's International Programme for the Elimination of Child Labor (ILO-IPEC) produced a child labor monitoring program that included self-monitoring and reporting components, in which local football manufacturers declared whether they had encountered any child labor in their football stitching supply chains. Participating football manufacturers in Sialkot hired internal auditors. The self-reported findings were double-checked by the ILO-IPEC's monitors between 1998 and 2003. However, by 2003-2004, the external monitoring mechanism was taken over by a newly formed, local, nonprofit organization, the Independent Monitoring Association for Child Labor (IMAC). Unlike ILO-IPEC, a donor-funded initiative, IMAC was expected to be a self-sustainable mechanism, mostly funded by the local industry and the Pakistan government. Most international buyers in the Sialkot football cluster insisted that suppliers to join ILO-IPEC and then IMAC. Nike and Adidas also performed their own independent, thirdparty monitoring, because they lacked confidence in the IMAC's independence and ability to ensure the strict monitoring of child labor and broader labor rights in this cluster (Lund-Thomsen and Nadvi 2010).
}

\section{Political Economy of Aid in Sialkot}

A significant reason why the CSR SME network was discontinued in Sialkot appeared to be that IDA withdrew from the project before the CSR SME network could be fully institutionalized within the cluster. As one network member explained,

This network was in between success and failure, because the project was initiated by IDA, and it was [then] discontinued and rolled back after some time. The project had a very short life cycle, whereas the CSR SME network was at the initial stages [of its formation]. The entrepreneurs wanted that since the project was initiated in collaboration with IDA, IDA should fund the project. Not only marketing the Soccer Village products but also arranging for the participation of the network members in foreign exhibitions. IDA should have facilitated the promotion and introduction of the project to the market.

In other words, the entrepreneurs expected IDA to shoulder a substantial part of the costs of initiating the project. They also anticipated that the agency would finance the initial participation of network members in foreign trade fairs. However, from the viewpoint of IDA, these assumptions of the SME network members in Sialkot reflected their failure to appreciate the importance of the entrepreneurs making their own financial contributions to the project. A key principle of IDA's cluster development approach is that project activities should not be undertaken solely through IDA funding. The lack of commitment by the SME network members to the project thus constituted an important reason that IDA discontinued its support.

However, even as representatives of the European IDA headquarters explained the dissolution of the Soccer Village project by citing a lack of engagement by local stakeholders, other stakeholders asserted that insufficient time had passed for IDA to convince the entrepreneurs of the business case for CSR or for the network members to invest in the functioning of the Soccer Village network. For example, a local nonprofit representative, who followed the evolution of the CSR SME network closely, noted,

The CSR SME network of IDA could not materialize, although seminars and workshops were held and awareness was created about this project. IDA left early. IDA should have conceived the idea in a better way. A proper feasibility study should have been conducted to determine if this could be achieved. IDA should have replicated some other design, which had proved successful in some other area, sector, or country. IDA phased out early and could not persuade 
the industrialists. It takes time to make something like this, which could work in Sialkot.

According to IDA's own guidelines for cluster development, a minimum period of 3-5 years is required for its approach to work in a given setting. So why would IDA initiate a CSR project aimed at promoting collective action among SMEs in Sialkot, through the establishment of the CSR SME network, and then withdraw before the usually recommended period of at least three years? We found two possible answers to this question. First, IDA had not initially committed the funds to sustain the project for the minimum recommended period. Financial support for the CSR SME network project came from IDA headquarters' global project for CSR in industrial clusters, funded by a bilateral donor in Europe. This project ran from 2005 to 2008, and it included activities in various countries in Asia, Africa, and Latin America. However, unlike the practice for other participating countries, there was no specific budget allocation for Pakistan. Thus, as pointed out by one of the staff members in IDA's European headquarters,

The Sialkot CSR project was formulated as part of a global initiative, which was not specifically aimed at Pakistan, and there was no specific allocation of money for Pakistan as such. Money was devoted to specific activities in Pakistan on a needs basis, not on the basis of some initial planning.

Second, the termination of IDA's global program for CSR in industrial clusters at the end of 2008 coincided with the possible closure of IDA's office in Lahore, Pakistan, which had been particularly devoted to industrial cluster development. According to IDA's international headquarters, by the end of 2008, the lack of buy-in for cluster development in Pakistan had become evident, so further investments of project resources in the country needed to be terminated. In IDA's Lahore-based office, the realization was also dawning that it was running out of project funds to sustain its ongoing interventions. Engaging in the CSR SME project enabled it to continue its work on industrial clusters temporarily and keep the Lahore-based office open, even without funding secured for the CSR SME network intervention for the usual, recommended three-year period.

\section{National Context of Pakistan}

It was not just internal IDA dynamics that exerted an influence though. The wider political context of work and employment in Pakistan also led IDA to withdraw relatively quickly from the CSR SME project, as confirmed by both the local project manager in Pakistan and a representative from IDA's European headquarters. In the words of the local project manager,

IDA had to wind up early due to the poor alignment of the initial road map with the actual activities, due to the worsening security situation of Pakistan. It was difficult for local and international IDA teams to continue their work in Sialkot due to the security situation.

A bomb blast in the Federal Investigation Authority building on Mall Road, Lahore, on March 11, 2008, was located very close to the Pearl Continental and Avari Hotels, where the IDA team stayed during its visit to Lahore in 2006-2007. In 2008 and 2009, IDA teams were forced to cancel visits to Pakistan, because they could not obtain the security clearance from the United Nations to travel there. The effect of the overall security situation in Pakistan on the CSR SME network project was confirmed by a representative from IDA's headquarters,

We had quite a lot of activities initially for the first year and a half. We also had a joint mission with the head of the Fair Labor Association, and we planned several activities related to engaging buyers to improve the situation in Sialkot. Sadly, we had to place our team on hold for quite some time due to the worsened security situation in Pakistan.

\section{Joint Action Among SMEs in the Sialkot Cluster}

In IDA's Lahore office in 2008, the head of the industrial cluster development team was eager to demonstrate progress in CSR work in Sialkot after Nike's withdrawal, yet the Lahore office was running out of funds. He therefore decided to bypass the usual process of training potential network members in IDA's cluster development methodology, which included networking and trust-building exercises to strengthen linkages among potential network members and enhance the capacity of the cluster associations to support SME networking within the cluster. This decision was not endorsed by IDA's international headquarters. From its point of view, launching such a project in a cluster in which social capital formation was skewed would have been premature and unlikely to produce the expected results. Nevertheless, to get the project activities going, the local IDA cluster development office in Lahore decided to approach the head of the Sialkot Chamber of Commerce to ask for support to launch an IDA-backed CSR project in Sialkot. The then-President was a football manufacturer; he and four of his family members owned football-manufacturing plants, and he believed that his own firm and those of his relatives might benefit from receiving 
capacity building, advice, and financial resources from IDA as part of this program.

Although this connection was a convenient means for IDA's Lahore-based office to initiate project activities relatively quickly on the ground, it also embodied, even if unintentionally, a fundamental contradiction between IDA's cluster development methodology that emphasized networking and trust-building among SMEs on the one hand and the historical evolution of the Chamber of Commerce president's network of SME businesses in the football-manufacturing industry on the other hand. At the time of the launch of the CSR SME network in Sialkot, the preexisting family networks that participated in the project had undergone processes of decentralization, growth, and expansion in the preceding decades. Family businesses often split into multiple units, so that different family members could take ownership and charge of their own business units. But, the emphasis of IDA's trust-building and networking approach was to bring the SMEs closer to one another, as articulated by a local IDA staff member in Pakistan:

The CSR SME network was an attempt to reunite the family businesses through the concept of networking and trust building. Network members did not pass through the individual and joint visioning processes to identify the common problems of network members. Network members did not conduct the fortnightly strategic meetings to initiate joint actions through the network's platform. CSR SME members were required to pass through the network building process for at least 3 years whereas the network was terminated only after 18 months of operation.

Thus, internal conflicts arose in this family network of businesses, including a generation gap between an older member of the family network, the then-President of the Chamber of Commerce, and younger members of the family who wanted to run their businesses without interference from their fathers or uncles. It then became impossible for IDA's ground-level staff to engage network members in trust-building or networking processes. Many of the main actors in the network simply were not interested in getting closer to their family members. Instead, they wished to further distance themselves from their relatives when it came to running their individual SME units.

The difficulties of implementing IDA's trust-building and networking approach cannot be attributed solely to internal power dynamics within the network though. Different areas of potential cooperation might have been easier to pursue. For example, the CSR SME network concept entailed, at least on paper, joint marketing of its CSR profile to international customers. However, whereas individual SME members might have been inclined to cooperate on production issues (e.g., joint purchasing of raw materials), the notion of sharing information about customers or even sharing clients was far more difficult to accept and thus was unlikely to spark cooperation among SME network members. As one member explained,

In my view, the concept [of networking and trustbuilding among SMEs] is unique but requires a higher level of trust and information sharing by the member companies. I also feel that one of the major benefits of networking is outsourcing within the network members but that, again, requires a higher level of trust and confidence amongst the members.

It thus appears as if the CSR SME network case does not match the usual optimism in prior literature on industrial clusters in developing countries that highlights the potential benefits for SMEs of engaging in active cooperation with one another. In this case, IDA's international headquarters wanted to test the assumption that CSR could provide a basis for promoting collective action within SME clusters, especially when cluster-based firms faced the threat of losing international orders to international clients due to their insufficient engagement in CSR. Yet to the extent that such collaborative efforts involved direct contacts with international clients, SME network members had strong incentives not to cooperate, because when one member obtains a new order from an international client as a result of the CSR SME network project, it might not generate immediate financial benefits for all network members.

\section{SME Perceptions of CSR in Sialkot}

Prior studies document that CSR compliance pressures can be perceived as a form of economic or cultural imperialism by SME managers in the developing world. For example, international buyers often demand constant price declines from suppliers but increased CSR investments, without being willing to share those costs. Managers in exportoriented enterprises also assert that some of the social conditions placed on their enterprises are culturally inappropriate in their local work and employment context (De Neve 2009; Khan and Lund-Thomsen 2011; Ruwanpura and Wrigley 2011). The perceptions of the CSR SME network members reflected these beliefs. One international scholar studying the project uncovered a perception among the CSR SME network members that buyers claimed they wanted to engage suppliers in socially responsible 
practices, but the buyers were themselves engaging in socially irresponsible practices, as evidenced in Nike's pull out from Saga Sports ${ }^{4}$ :

The timing of IDA's entry into Sialkot to undertake a [CSR] intervention was not appropriate, as Nike had recently terminated its sourcing of soccer balls from its lead supplier, Saga Sports, in Pakistan due to allegations of child labor in the production chain, leaving 7000 workers unemployed as an outcome. The actions of Nike under the heading of CSR were not received positively by the football producers in Sialkot. In fact, the manufacturers and exporters in Sialkot felt a lot of resentment towards the notion of CSR. People [manufacturers] in Sialkot believed that compliance issues related to child labor would fade away with the passage of time as the buyers were actually looking for cheaper products, and that compliance with CSR issues was an issue that was related to the negotiation and bargaining power of the buyers and brands.

Therefore, the CSR SME network members did not consider compliance with the CSR requirements of international buyers an immediate concern. At the same time, some CSR SME network members believed that the Sialkot football-manufacturing industry suffered a negative international image due mainly to the work of international funding agencies or Western media. Rather than seeing the decline of the hand-stitched football-manufacturing industry in Sialkot as a result of a lack of technological upgrading, production scale, changing buyer demands, or low worker productivity (as indicated by Lund-Thomsen et al. 2012; Nadvi et al. 2011), they accused international nonprofit and UN agencies as being responsible for the decline in Sialkot's overall share of global footballmanufacturing exports. As one network member observed,

International agencies including NGOs will never participate in image building [of the industry], but will always create negative branding. They are directly responsible for [the] destruction of [the Sialkot] soccer ball industry, as exhibited by the decrease in the industry's market share from 80 to $9 \%$. These agencies are directly responsible for unemployment of 1.1-1.4 million families. Do they want more? The hand-stitched soccer ball industry is finished due to [the actions of] these agencies.

Thus, IDA sought to initiate the CSR SME network at a time, when there was particularly widespread resentment among local manufacturers against the CSR initiatives

\footnotetext{
${ }^{4}$ The network members were talking specifically about the International Labor Rights Forum (ILRF) here.
}

promoted by international NGOs, buyers, and funding agencies. In the view of some network members, the negative publicity created by these international entities and media outlets had damaged the industry's reputation beyond repair. That is,

I will say that in case of hand-stitched ball business, external factors, mainly NGOs and others, have brought this craft industry to such a level that no more damage can be done.

Yet as one scholar we interviewed was careful to note, the negative views of CSR SME network members toward international aid agencies and their CSR activities in Sialkot were not just an outcome of the SME network members' subjective perceptions. True, actual, negative social consequences in the cluster had emerged for many stitcher families, as a result of the decline in the handstitching business, while some other local actors, including NGOs, had benefitted from being able to obtain more funds for their social work in Sialkot:

Women and children lost work due to local manufacturers' non-compliance with international CSR demands on the one hand, whereas [local and international] NGOs mobilized funds out of this crisis on the other.

Because IDA tried to introduce a cluster-based CSR initiative in Sialkot at a time when local SME manufacturers were especially frustrated with what they perceived to be the double standards of international buyers, UN agencies, and NGOs, it is hardly surprising that the CSR SME network members were not particularly keen on continuing the network once the external driver of IDA left in 2009 .

\section{Conclusions}

With this article, we set out to explore whether donorfinanced CSR projects might help or hinder the promotion of collective action among SMEs in industrial clusters in developing countries, in response to international buyers' concern with CSR compliance downstream in their global value chains. We propose a novel analytical framework, linking literature on (private sector) development aid, institutional approaches to CSR, industrial clusters, and CSR in developing countries. In analytical terms, we thus contribute to literature on CSR in industrial clusters in developing countries by identifying some factors that likely explain why international donor-financed CSR projects succeed or fail to promote collective action in such clusters. We argue that donor-funded CSR interventions have the potential to facilitate the joint access of SMEs to 
demanding consumer markets in developed countries if they are concretely linked to social and environmental upgrading of SMEs, with know-how and training provided over a sustained period to SME network members, initiatives that form part of broader multi-stakeholder initiatives that link local SME networks to global buyers, and support provided for joint action initiatives with business associations. However, donor-funded CSR initiatives likely fail to promote collective action among cluster-based SMEs when there is no clearly perceived business case (i.e., financial rationale) for CSR engagement, when cluster-based SMEs are insufficiently involved in project formulation, when CSR is perceived by SMEs as a form of economic or cultural imperialism, and when donor funding is provided for a relatively short period. The latter circumstances appear to have been prevalent in the case of the CSR SME network we have studied herein.

So what are the wider implications for our understanding of donor support for CSR interventions in industrial clusters in developing countries? The CSR SME network offers a clear example of how internal dynamics within donor agencies influence on-the-ground implementations of project activities. Without proper planning and execution, donor-financed CSR interventions are unlikely to be able to support collective action processes within clusters sustainably. However, the CSR SME network case also demonstrates that even if such planning and execution had taken place, with sufficient financing, there may be realistic limits to what CSR projects can achieve in national contexts that are characterized by political instability, unrest, and security threats. It simply becomes unfeasible to conduct project activities at the ground level in such circumstances. Contrary to a widespread assumption in research on industrial clusters in developing countries-namely, that SMEs benefit from engaging in collective action initiatives - the internal dynamics and conflicts of interest within SME networks can create strong disincentives for network members to engage in joint action. Finally, the assumption that CSR can promote collective action in industrial clusters in developing countries does not always hold, especially if SME managers view CSR as a form of economic and cultural imperialism. The opposition to Western-style CSR interventions may be so strong that they actually hinder the implementation of projects or result in entrepreneurs sensing no ownership of the projects, which undermines the long-term viability of any such interventions.

Thus, as Newell (2005, p. 556) predicted, "CSR can work, for some people, in some places, on some issues, some of the time." The intellectual challenge is to specify the circumstances in which CSR interventions promote joint action in industrial clusters and produce positive outcomes for local SMEs, workers, and communities, while also recognizing that the interests of these actors do not always align. In some circumstances, they even might come in direct conflict, so policy makers must be clear about whether sufficient social capital exists in SME networks to sustain joint action initiatives. This effort also necessitates consideration of how local SME entrepreneurs perceive CSR and whether they are likely to support any such engagement.

In terms of research pathways, we are clearly in need of more empirical studies that can explicate the circumstances in which CSR interventions in industrial clusters in developing countries work for some people, some firms, in some places, some of the time. Despite recent advances in conceptual understanding of the links between industrial clusters and CSR in developing countries, we still face a dearth of studies that investigate the outcomes of donorsponsored CSR interventions in industrial clusters in developing countries. For example, IDA and the ILO have undertaken a range of CSR projects in India and Pakistan, but beyond a few select insights, we know relatively little about the potential and limitations of this approach to private sector development in developing countries.

Acknowledgments Alex Michalos served as editor for this article.

Open Access This article is distributed under the terms of the Creative Commons Attribution 4.0 International License (http://creative commons.org/licenses/by/4.0/), which permits unrestricted use, distribution, and reproduction in any medium, provided you give appropriate credit to the original author(s) and the source, provide a link to the Creative Commons license, and indicate if changes were made.

\section{Appendix}

See Table 4.

Table 4 International literature on CSR in the Sialkot football cluster

\begin{tabular}{llll}
\hline Author(s) & Key findings & Limitations & Role of donor-funded CSR \\
\hline $\begin{array}{l}\text { Kazmi and } \\
\text { McFarlane } \\
(2003)\end{array}$ & $\begin{array}{c}\text { Child labor was eliminated in soccer ball manufacturing } \\
\text { as a result of the Atlanta agreement. Skilled, male } \\
\text { stitchers earned higher wages. A reduction took place } \\
\text { in family incomes as fewer family members engaged } \\
\text { in stitching }\end{array}$ & $\begin{array}{c}\text { The data generation } \\
\text { methodology is not } \\
\text { specified in detail }\end{array}$ & $\begin{array}{c}\text { It mentions the role of donor funding } \\
\text { agencies but does not contain any in-depth } \\
\text { analysis of their functioning }\end{array}$ \\
\hline
\end{tabular}


Table 4 continued

\begin{tabular}{|c|c|c|c|}
\hline Author(s) & Key findings & Limitations & Role of donor-funded CSR \\
\hline $\begin{array}{l}\text { Khan } \\
(2004)\end{array}$ & $\begin{array}{l}\text { The reality of child labor eradication } \\
\text { programs in Sialkot does not match the } \\
\text { glossy descriptions of international } \\
\text { donor agencies advocating these } \\
\text { approaches. Child labor appeared to be } \\
\text { eradicated in the industry as a result of }\end{array}$ & $\begin{array}{l}\text { The study was mainly qualitative, based } \\
\text { on a limited number of interviews with } \\
\text { firms, subcontractors, and football } \\
\text { stitchers in the industry }\end{array}$ & $\begin{array}{l}\text { It discusses the role of donor funding } \\
\text { agencies in promoting the eradication } \\
\text { of child labor within the Sialkot football } \\
\text { cluster. It portrays these agencies as } \\
\text { agents of economic and cultural } \\
\text { imperialism }\end{array}$ \\
\hline
\end{tabular}

The leading football manufacturer Saga Khaliq Sports is a CSR-conscious company. A (2004) change of attitude is needed among small-scale entrepreneurs and contractors in the cluster if its CSR profile is to be improved

\begin{tabular}{|c|c|}
\hline $\begin{array}{l}\text { Khan } \\
\text { (2007a, } \\
\text { b) }\end{array}$ & $\begin{array}{l}\text { The discourse about child labor } \\
\text { eradication in the Sialkot football- } \\
\text { manufacturing industry is perceived as } \\
\text { a form of economic and cultural } \\
\text { imperialism by many football- } \\
\text { manufacturing firms, NGOs, and } \\
\text { football stitchers in Sialkot. The child } \\
\text { labor eradication programs in Sialkot } \\
\text { led to the widespread exclusion of } \\
\text { female stitchers from the labor force }\end{array}$ \\
\hline $\begin{array}{c}\text { Seigmann } \\
(2008)\end{array}$ & $\begin{array}{l}\text { The CSR performance of Nike's two } \\
\text { football suppliers in Sialkot, Saga } \\
\text { Sports and Silverstar, surpass those of } \\
\text { other companies in the industry. } \\
\text { However, minimum wages were not } \\
\text { paid, discriminatory recruitment } \\
\text { practices were employed, and } \\
\text { environmental management was weak } \\
\text { at these two companies }\end{array}$ \\
\hline $\begin{array}{l}\text { Lund- } \\
\text { Thomsen } \\
\text { and } \\
\text { Nadvi } \\
(2010)\end{array}$ & $\begin{array}{l}\text { Local child labor monitoring systems } \\
\text { appear more rigorous in clusters that } \\
\text { supply mega-brands such as Nike and } \\
\text { Adidas. However, in clusters where } \\
\text { external scrutiny from multinational } \\
\text { companies is less intense, there may be } \\
\text { more space for local actors to develop } \\
\text { "indigenous" CSR models }\end{array}$ \\
\hline $\begin{array}{l}\text { Khan and } \\
\text { Lund- } \\
\text { Thomsen } \\
\text { (2011) }\end{array}$ & $\begin{array}{l}\text { SR in Sialkot is a kind of Western } \\
\text { economic and cultural imperialism, } \\
\text { aimed at subjugating local suppliers }\end{array}$ \\
\hline
\end{tabular}

Nadvi et al. Compliance with labor standards in the (2011) Asian sports goods industry has different implications for the geographically dispersed producer locations in Indian, Pakistan, China, and Thailand. Complying with labor standards is an insufficient basis for Pakistan, India, and Thailand to compete with the Chinese sports goods industry. Other factors, such as
Only three interviews were conducted, and the information was not triangulated. Saga Sports, is praised in the article, closed three years later after as Nike cut its ties, on the basis of labor rights violations and unauthorized outsourcing of football stitching to home-based locations

The findings are based on ethnographic fieldwork in Sialkot. It is thus hard to establish whether the author's thick description of the working lives of entrepreneurs, subcontractors, and football stitchers can be generalized to the industry as a whole or only the limited number of informants interviewed for the study

The data generation was quite limited. The descriptions of working conditions were based on a brief visit to Sialkot and interviews with an unspecified number of workers. The only other stakeholders interviewed were from the Pakistani Institute of Labor Education and Research and Silverstar's management

The study was not based on a large, quantitative survey of firms, which would have allowed the authors to generalize the findings of their study to all firms in the Sialkot and Jalandhar clusters

Only qualitative interviews were undertaken with a limited number of football manufacturer and stitchers. No large-scale quantitative study of firm perceptions of CSR in the Sialkot football-manufacturing industry backs up the findings

A fairly limited number of firms were interviewed, so it may not be possible to generalize the findings to all firms operating in the football-manufacturing industries of Pakistan, India, and China
It does not deal specifically with the role of donor agencies

It contains a very critical discussion of the role of donor agencies in promoting the eradication of child labor within the cluster. These agencies are seen as agents of economic and cultural imperialism

It does not contain an in-depth discussion of the role of donor agencies in the cluster

It contains a comparative analysis of the implementation of the Atlanta agreement in the Sialkot and Jalandhar football-manufacturing clusters. The article argues that the implementation was more donor and brand driven in Sialkot than in Jalandhar

It does not contain any in-depth analysis of the role of donor agencies in the Sialkot cluster

It does not contain any in-depth discussion of the role of donor agencies in the promotion of CSR within the cluster 
Table 4 continued

\begin{tabular}{|c|c|c|c|}
\hline Author(s) & Key findings & Limitations & Role of donor-funded CSR \\
\hline $\begin{array}{l}\text { Nadvi } \\
\quad(2011)\end{array}$ & $\begin{array}{l}\text { Concerns over labor standard compliance } \\
\text { and product and process upgrading } \\
\text { shape the economic geography of } \\
\text { football manufacturing in Asia. This } \\
\text { has implications for individual producer } \\
\text { countries such as Pakistan and China }\end{array}$ & $\begin{array}{l}\text { The study was mainly based on } \\
\text { qualitative interviews with international } \\
\text { buyers and suppliers in Pakistan, India, } \\
\text { and China. No quantitative survey was } \\
\text { undertaken of either the brands or } \\
\text { suppliers in these three different } \\
\text { countries }\end{array}$ & $\begin{array}{l}\text { It does not look at the role of donor } \\
\text { agencies in the Sialkot cluster }\end{array}$ \\
\hline $\begin{array}{l}\text { Lund- } \\
\text { Thomsen } \\
\text { et al. } \\
\text { (2012) }\end{array}$ & $\begin{array}{l}\text { Empirical studies of labor standards and } \\
\text { CSR in global value chains are too } \\
\text { narrow in their focus. Instead studies } \\
\text { need to engage with questions of } \\
\text { economic, technological, and social } \\
\text { upgrading to obtain a better } \\
\text { understanding of why workers labor in } \\
\text { similar or different conditions in } \\
\text { export-oriented industries in developing } \\
\text { countries }\end{array}$ & $\begin{array}{l}\text { The study of worker' conditions in the } \\
\text { football-manufacturing industries of } \\
\text { Pakistan, India, and China is only based } \\
\text { on a limited number of qualitative } \\
\text { interviews with stitchers. No } \\
\text { quantitative surveys were undertaken, } \\
\text { which might have allowed the authors } \\
\text { to generalize their findings more } \\
\text { broadly }\end{array}$ & $\begin{array}{l}\text { It does not discuss the role of donor } \\
\text { agencies in industrial cluster } \\
\text { development in Sialkot }\end{array}$ \\
\hline $\begin{array}{l}\text { Lund- } \\
\text { Thomsen } \\
(2013)\end{array}$ & $\begin{array}{l}\text { Labor agency in Sialkot is highly } \\
\text { gendered and tends to be more } \\
\text { constrained than facilitated by the } \\
\text { governance of global production } \\
\text { networks and the local socio-economic } \\
\text { and labor market context in Sialkot }\end{array}$ & $\begin{array}{l}\text { The study of labor agency in Sialkot was } \\
\text { based on a limited number of } \\
\text { qualitative interviews with workers. No } \\
\text { quantitative survey was undertaken of } \\
\text { work conditions and labor agency to } \\
\text { allow the author to generalize the } \\
\text { findings to all football stitchers } \\
\text { employed in Sialkot's football industry }\end{array}$ & $\begin{array}{l}\text { It does not look at the role of donor } \\
\text { agencies in promoting CSR in the } \\
\text { Sialkot cluster }\end{array}$ \\
\hline $\begin{array}{l}\text { Scamardella } \\
\text { (2015) }\end{array}$ & $\begin{array}{l}\text { In considering the Atlanta agreement as } \\
\text { an example of legal pluralism (neither } \\
\text { hard nor soft law), the author argues } \\
\text { that if legal pluralism is to be more } \\
\text { efficient than hard law, it must } \\
\text { overcome two potential problems: (lack } \\
\text { of) democratic participation and the risk } \\
\text { of imperialism }\end{array}$ & $\begin{array}{l}\text { The study was based on a review of } \\
\text { secondary literature about the Atlanta } \\
\text { Agreement and its implementation in } \\
\text { Sialkot. No primary data appears to } \\
\text { have been collected for the study }\end{array}$ & $\begin{array}{l}\text { Donor funding is a not a key subject of } \\
\text { debate in this article }\end{array}$ \\
\hline $\begin{array}{l}\text { Lund- } \\
\text { Thomsen } \\
\text { and Coe } \\
(2015)\end{array}$ & $\begin{array}{l}\text { Using the case of Nike in Sialkot, the } \\
\text { authors argue that the CSR policies of } \\
\text { global retailers can create enhanced } \\
\text { space for labor agency in global } \\
\text { production networks. However, the } \\
\text { possibilities for such labor agency to be } \\
\text { exercised are also shaped by national } \\
\text { actors and regulatory frameworks }\end{array}$ & $\begin{array}{l}\text { The study is based on a limited number of } \\
\text { qualitative interviews with workers. No } \\
\text { quantitative survey was undertaken of } \\
\text { work conditions and labor agency that } \\
\text { would have allowed the authors to } \\
\text { generalize the findings to all workers } \\
\text { employed in Nike's production network } \\
\text { in Sialkot }\end{array}$ & $\begin{array}{l}\text { It does not contain any discussion of the } \\
\text { role of donor funding agencies in } \\
\text { promoting CSR in the Sialkot football- } \\
\text { manufacturing industry }\end{array}$ \\
\hline
\end{tabular}

\section{References}

Altenburg, T. (2007). Donor approaches to supporting pro-poor value chains. Report prepared for the Donor Committee for Enterprise Development Working Group on Linkages and Value Chains, DCED/GDI, Bonn.

Azizi, S., \& Jamali, D. (2015). CSR in the telecommunications industry of Afghanistan. South Asian Journal of Global Business Research, forthcoming.

Barrientos, S., \& Smith, S. (2007). Do workers benefit from ethical trade? Assessing codes of labour practice in global production systems. Third World Quarterly, 28(4), 713-729.

Blackman, A. (2006). Small firms and the environment in developing countries: Collective action and collective impacts. Washington, DC: RFF Press.

Brammer, S., Jackson, G., \& Matten, D. (2012). Corporate social responsibility and institutional theory: new perspectives on private governance. Socio-Economic Review, 10(1), 3-28.
Browne, S. (Ed.). (2006). Aid and influence: Do donors help or hinder? New York: Earthscan.

Chan, A., \& Xue, H. (2013). The global value chain. Value for whom? The soccer ball industry in Pakistan and China. Critical Asian Studies, 45(1), 55-77.

De Neve, G. (2009). Power, inequality and corporate social responsibility: The politics of ethical compliance in the South Indian garment industry. Economic and Political Weekly, 4(22), 63-71.

De Neve, G. (2014). Fordism, flexible specialization and CSR: Indian garment workers critique neoliberal labour regimes. Ethnography, 15(4), 184-209.

Easterly, W. (2007). The white man's burden: Why the West's efforts to aid the rest have done so much ill and so little good. Oxford: Oxford University Press.

Egels-Zandén, N. (2015). The role of SMEs in global production networks: A Swedish SME's payment of living wages at its Indian supplier. Business \& Society, (in Press). 
Eisenhardt, K. M. (1989). Building theories from case study research. Academy of Management Review, 14(4), 532-550.

Estrup, J. (2009). Aid, Paris, and the private sector: How to square the circle, DIIS Working 2009:17. Copenhagen: Danish Institute of International Studies.

Feeny, S., \& McGillivray, M. (2009). Aid allocation to fragile states: absorptive capacity constraints. Journal of International Development, 21(5), 618-632.

Flyvbjerg, B. (2006). Five misunderstandings about case study research. Qualitative Inquiry, 12(2), 219-245.

FMC. (2013a). Fostering business responsibility in MSME clusters: Role of policy makers (Vol. 1). New Delhi: FMC.

FMC. (2013b). Fostering business responsibility in MSME clusters: Role of implementing agencies (Vol. II). New Delhi: FMC.

FMC. (2013c). Fostering business responsibility in MSME clusters: Role of cluster development agents (Vol. III). New Delhi: FMC.

Gereffi, G. \& Lee, J. (2014). Economic and social upgrading in global value chains and industrial clusters: Why governance matters. Journal of Business Ethics, (in press).

Gibbon, P., \& Ponte, S. (2005). Trading down: Africa, value chains and the global economy. Philadelphia, PA: Temple University Press.

Gisselquist, R. (2014). Introduction: aid and institution building in fragile states: What do we know? What can comparative analysis add? Annals of the American Academy of Political and Social Science, 656(1), 6-21.

Giuliani, E. (2005). Cluster absorptive capacity: Why do some clusters forge ahead and others lag behind. European Urban and Regional Studies, 12(3), 269-288.

Giuliani, E. (2014). Human rights and corporate social responsibility in developing countries' industrial clusters, Journal of Business Ethics, in press.

Giuliani, E., Pietrobelli, C., \& Rabellotti, R. (2005). Upgrading in global value chains: Lessons from Latin American clusters. World Development, 33(4), 549-573.

Gond, J. P., Kang, N., \& Moon, J. (2011). The government of selfregulation: On the comparative dynamics of corporate social responsibility. Economy and Society, 40(4), 640-671.

Groves, L., \& Hinton, R. (2013). Inclusive aid: Changing power and relationships in international development. London: Earthscan.

Gulati, M. (2012). Business responsibility: Global value chains, industrial clusters, and the future of CSR in India. Paper presented at Global value chains, industrial clusters, and the future of CSR in the BRICS countries, Copenhagen Business School, 12-14 December, Copenhagen.

Hancock, G. (1994). Lords of poverty: The power, prestige, and corruption of the international aid business. New York: Atlantic Monthly Press.

Humphrey, J. \& Navas-Aleman, L. (2010). Value chains, donor interventions, and poverty reduction: A review of donor practice. Research Report 63, Institute of Development Studies, University of Sussex.

Hussein-Khaliq, S. (2004). Eliminating child labour from the Sialkot soccer ball industry: Two industry-led approaches. Journal of Corporate Citizenship, 13(Spring), 101-107.

International Labor Rights Forum (ILRF). (2010). Missed the goal for workers: The reality of football stitchers in India, Pakistan, China, and Thailand. Washington, DC: ILRF.

Jamali, D., Lund-Thomsen, P., and Khara, N. (2015). CSR institutionalized myths in developing countries: An imminent threat of selective decoupling. Business \& Society, (in press).

Kazmi, B., \& Macfarlane, M. (2003). The impact of CSR strategies: The case of child labour elimination. In R. O'Sullivan \& M. Robinson (Eds.), Business and human rights: Dilemmas and solutions. London: Greenleaf.

Khan, F. R. (2004). Hard times recalled: the child labour controversy in Pakistan's soccer ball industry. In F. Bird, E. Raufflet, \& J.
Smucker (Eds.), International business and the dilemmas of development: Case studies in South Africa, Madagascar, Pakistan, South Korea, Mexico, and Columbia (pp. 132-155). London: Palgrave MacMillan.

Khan, F. R. (2007a). Representational approaches matter. Journal of Business Ethics, 73(1), 77-89.

Khan, A. (2007b). Power, policy and the discourse on child labour in the football manufacturing industry of Sialkot. Karachi: Oxford University Press.

Khan, A. (2010). Peshgi without bondage: Reconsidering the links between debt and forced labor. Cultural Dynamics, 22(3), 247-266.

Khan, F. R., \& Lund-Thomsen, P. (2011). CSR as imperialism: Towards a phenomenological approach to CSR in the developing world. Journal of Change Management, 11(1), 73-90.

Knorringa, P., \& Nadvi, K. (2014). Rising power clusters and the challenges of global and local standards. Journal of Business Ethics, (in press).

Kragelund, P. (2005). Donor, dollars, and development: Insights into the impacts of Danida's private sector development programme in Ghana. Ph.D. thesis, Roskilde University, Roskilde.

Lund-Thomsen, P. (2008). The global sourcing and codes of conduct debate: Vive myths and five recommendations. Development and Change, 39(6), 1005-1018.

Lund-Thomsen, P. (2009). Assessing the impact of public-private partnerships in the global South: The case of the Kasur Tanneries pollution control project. Journal of Business Ethics, 90(1), 57-78.

Lund-Thomsen, P. (2013). Labor agency in the football manufacturing industry of Sialkot, Pakistan. Geoforum, 44(1), 71-81.

Lund-Thomsen, P., \& Coe, N. (2015). Corporate social responsibility and labor agency: The case of Nike in Pakistan. Journal of Economic Geography, 15(2), 275-296.

Lund-Thomsen, P., Lindgreen, A., \& Vanhamme, J. (2014). Industrial clusters and corporate social responsibility in developing countries: What we know, what we don't, and what we need to know. Journal of Business Ethics, (in press).

Lund-Thomsen, P. \& Nadvi, K., (2009). Global value chains, local clusters, and corporate social responsibility: A comparative assessment of the sports goods clusters in Sialkot, Pakistan and Jalandhar, India. Technical Paper 17, Industrial Policy and Private Sector Development Branch, United Nations Industrial Development Organisation, Vienna.

Lund-Thomsen, P., \& Nadvi, K. (2010). Clusters, chains, and compliance: Corporate social responsibility and governance in football manufacturing in South Asia. Journal of Business Ethics, 93(Suppl 1), 201-222.

Lund-Thomsen, P., Nadvi, K., Chan, A., Khara, N., \& Xue, H. (2012). Labor in global value chains work conditions in football manufacturing in China, India, and Pakistan. Development and Change, 43(6), 1211-1237.

Lund-Thomsen, P., \& Pillay, R. G. (2012). CSR in industrial clusters: An overview of the literature. Corporate Governance, 12(4), $568-578$.

Matten, D., \& Moon, J. (2008). Implicit and explicit CSR: A conceptual framework for a comparative understanding of corporate social responsibility. Academy of Management Review, $33(2), 404-424$.

Mavrotas, G. (2010). Foreign aid for development: Issues, challenges, and the new agenda. Oxford: Oxford University Press.

Mawdsley, E. (2012). From recipients to donors: Emerging powers and the changing development landscape. London: Zed Books.

McCracken, G. (1986). The long interview. Newbury Park, CA: Sage.

Morrison, A., Rabellotti, R., \& Zirulka, L. (2013). When do global pipelines enhance the diffusion of knowledge in clusters? Economic Geography, 89(1), 77-96. 
Nadvi, K. (1999a). Collective efficiency and collective failure: The response of the Sialkot surgical instrument cluster to global quality pressures. World Development, 27(9), 1605-1626.

Nadvi, K. (1999b). Shifting ties: social networks in the surgical instruments cluster of Sialkot, Pakistan. Development \& Change, $30(1), 141-175$.

Nadvi, K. (2004). The effect of global standards on local producers: A Pakistani case study. In H. Schmitz (Ed.), Local enterprises in the global economy: Issues of governance and upgrading (pp. 297-325). Cheltenham: Edward Elgar.

Nadvi, K. (2011). Labor standards and technological upgrading: Competitive challenges in the global football industry. International Journal of Technological Learning, Innovation, and Development, 4(1-3), 235-257.

Nadvi, K., Lund-Thomsen, P., \& Xue, H. (2011). Playing against China: global value chains and labour standards in the international sports goods industry. Global Networks, 11(3), 334-354.

Newell, P. (2005). Citizenship, accountability, and community: the limits of the CSR agenda. International Affairs, 81(3), 541-557.

North, D. C. (1990). Institutions, institutional change and economic performance. Cambridge: Cambridge University Press.

Nunnenkamp, P., Öhler, H., \& Thiele, R. (2013). Donor coordination and specialization: Did the Paris declaration make a difference? Review of World Economics, 149(3), 537-563.

Parks, T. (2008). The rise and fall of donor for advocacy NGOs: Understanding the impact. Development in Practice, 18(2), 213-222.

Pattaconi, G., \& Weisert, N. (2013). The UNIDO approach to sustainable supplier development-Promoting CSR for SMEs in global supply chain contexts. Vienna: UNIDO.

Pole, C., \& Lampard, R. (2002). Practical social investigation: Qualitative and quantitative methods in social research. Essex: Prentice Hall.

Puppim de Oliveira, J. A., \& Fortes, P. (2014). Global value chains and social upgrading of clusters: Two cases of fairtrade from the Brazilian northeast. Competition and Change, 18(4), 365-381.

Puppim de Oliveira, J. A., \& Jabbour, C. (2015). Environmental management, CSR and governance in clusters of small firms in developing countries: Towards an integrated analytical framework. Business \& Society, (in press).

Pyke, F., \& Sengenberger, W. (1992). Industrial districts and local economic regeneration. Geneva: International Institute of Labor Studies.

Reast, J., Lindgreen, A., Vanhamme, J., \& Maon, F. (2010). The Manchester super casino: Experience and learning in a cross- sector social partnerships. Journal of Business Ethics, 94(Suppl. 1), 197-218.

Reast, J., Maon, F., Lindgreen, A., \& Vanhamme, J. (2013). Legitimacy-seeking organizational strategies in controversial industries: A case study and a bidimensional model. Journal of Business Ethics, 118(1), 139-153.

Richmond, O. P. (2012). Beyond local ownership in the architecture of international peacebuilding. Ethnopolitics, 11(4), 354-375.

Riddell, R. (2007). Does foreign aid really work?. Oxford: Oxford University Press.

Ruwanpura, K., \& Wrigley, N. (2011). The costs of compliance? Views of Sri Lankan apparel manufacturers in times of global financial crisis. Journal of Economic Geography, 11, 1-19.

Scamardella, F. (2015). Law, globalization, governance: Emerging alternative legal techniques: The Nike scandal in Pakistan. Journal of Legal Pluralism and Unofficial Law, 47(1), 76-95.

Schmitz, H. (2004). Local enterprises in the global economy: Issues of governance and upgrading. Cheltenham: Edward Elgar.

Schmitz, H., \& Nadvi, K. (1999). Clustering and industrialization: Introduction. World Development, 27(9), 1503-1514.

Schulpen, L., \& Gibbon, P. (2002). Private sector development: Policies, practices, and problems. World Development, 30(1), $1-15$.

Seigmann, K. A. (2008). Soccer ball production for Nike. Economic and Political Weekly, 43(22), 57-64.

Skadesgaard Thorsen, S., \& Jeppesen. S. (2010). Changing course: A study into responsible supply chain management, Danish Ministry of Foreign Affairs/Copenhagen Business School, Copenhagen. http://um.dk/en/danida-en/activities/business/partnerships/b2b programme/news/newsdisplaypage/?newsid=f $45 \mathrm{f} 3 \mathrm{efc}-4 \mathrm{e} 1 \mathrm{f}-43 \mathrm{a}$ 9-a919-00bbb89c39b6.

Staritz, C. (2012). Value chains for development: Potential and limitations of global value chain approaches in donor interventions. Working Paper 31, Austrian Foundation for Development Research, Vienna.

Strauss, A., \& Corbin, J. (1998). Basics of qualitative research: Techniques and procedures for developing grounded theory. Newbury Park, CA: Sage Publications.

UNIDO. (2013). The UNIDO approach to cluster development: Key principles and project experiences for inclusive growth. Vienna: UNIDO.

Yin, R. (2013). Case study research: Design and methods. London: Sage Publications. 